\title{
Nurse training for care management: integrative literature review
}

\author{
Formação do enfermeiro para a gestão do cuidado: revisão integrativa da literatura \\ Capacitación del enfermero para la gestión del cuidado: revisión integrada de la literatura
}

Laís Barreto de Brito Gonçalves'
ORCID: 0000-0002-9429-2547

Rachel de Sá Barreto Luna Callou Cruz' ORCID: 0000-0002-4596-313X

Glauberto da Silva Quirino' ORCID: 0000-0001-5488-7071

Antonio Germane Alves Pinto' ORCID: 0000-0002-4897-1178

'Universidade Regional do Cariri. Crato, Ceará, Brazil.

How to cite this article:

Gonçalves LBB, Cruz RSBLC, Quirino GS, Pinto AGA. Nurse training for care management: integrative literature review. Rev Bras Enferm. 2022;75(3):e20201186. https://doi.org/10.1590/0034-7167-2020-1186

Corresponding author: Laís Barreto de Brito Gonçalves E-mail: laisynha1@hotmail.com

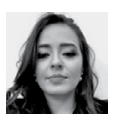

EDITOR IN CHIEF: Antonio José de Almeida Filho ASSOCIATE EDITOR: Priscilla Valladares Broca

Submission: 02-09-2021

Approval: 10-02-2021

\section{ABSTRACT}

Objectives: to identify how nurses are trained to manage care. Methods: an integrative review, guided by the research question: "How does the training of nurses for care management occur?" The studied performed the search on LILACS, BDENF, CINAHL, Cochrane Library, BVS, and SciELO, using combined strategies to select publications indexed in databases and electronic libraries. The analysis involved bibliometric aspects and the evidence on nursing education contained in the articles. The final sample consisted of eight articles. Results: three thematic categories emerged: conceptions and senses; fragmentation of care; and training practices. They showed essential aspects about the nurse training process for care management. Final Considerations: research needs to address conceptions inherent to teaching processes focusing on concepts, significance, and application, engaging the development of macro skills to transpose care beyond theory.

Descriptors: Nursing; Education, Nursing; Nursing Care; Comprehensive Health Care; Process Nursing.

\section{RESUMO}

Objetivos: identificar como ocorre a formação do enfermeiro para a gestão do cuidado. Métodos: revisão integrativa, norteada pela pergunta de pesquisa:"Como ocorre a formação do enfermeiro para a gestão do cuidado?" A busca foi realizada na LILACS, BDENF, CINAHL, Cochrane Library, BVS e SciELO, utilizando estratégias combinadas para seleção das publicações indexadas nas bases de dados e nas bibliotecas eletrônicas. A análise envolveu aspectos bibliométricos e as evidências sobre a formação em enfermagem contida nos artigos. A amostra final foi composta por oito artigos. Resultados: emergiram três categorias temáticas: Concepções e sentidos; Fragmentação do cuidado; e Práticas de formação. Evidenciaram aspectos importantes sobre o processo de formação do enfermeiro para a gestão do cuidado. Considerações Finais: as pesquisas precisam abordar concepções inerentes aos processos de ensino com foco nos conceitos, significância e aplicação, engajando o desenvolvimento de macrocompetências a fim de transpor o cuidado para além da teoria.

Descritores: Enfermagem; Educação em Enfermagem; Cuidados de Enfermagem; Integralidade em Saúde; Processo de Enfermagem.

\section{RESUMEN}

Objetivos: identificar como ocurre la capacitación del enfermero para la gestión del cuidado. Métodos: revisión integrada, orientada por la cuestión de investigación: "Como ocurre la capacitación del enfermero para la gestión del cuidado?" La búsqueda realizada en la LILACS, BDENF, CINAHL, Cochrane Library, BVS y SciELO, utilizando estrategias combinadas para selección de las publicaciones indexadas en las bases de datos y bibliotecas electrónicas. El análisis involucró aspectos bibliométricos y evidencias sobre la capacitación en enfermería contenida en los artículos. La muestra final composta por ocho artículos. Resultados: emergieron tres categorías temáticas: Concepciones y sentidos; Fragmentación del cuidado; y Prácticas de capacitación. Evidenciaron aspectos importantes sobre el proceso de capacitación del enfermero para la gestión del cuidado. Consideraciones Finales: las investigaciones precisan abordar concepciones inherentes a procesos de enseñanza con enfoque en conceptos, significación y aplicación, comprometiendo el desarrollo de macrocompetencias a fin de transponer el cuidado además de la teoría.

Descriptores: Enfermería; Educación en Enfermería; Atención de Enfermería; Integralidad en Salud; Proceso de Enfermería. 


\section{INTRODUCTION}

Nursing consists of the development of actions that centralize care and its integrality; it intends to contemplate aspects inherent in the proposal of unified assistance, transversal care, and with emphasis on a formation based on the concepts and definitions of health care ${ }^{(1-2)}$. Thus, it is necessary to understand how, in theory and practice, the training for the management of care in nursing.

From the definitions concerning management, healthcare management encompasses clinic, teaching, and integrality, in addition to care, and it operates under attitudinal and subjective perspectives. However, care management is a set of elements that involve the individual, family, professional, organizational, systemic, and corporate process and that, through the organization of these multiple aspects, contributes to the production of care ${ }^{(3-4)}$.

As a phenomenon, nursing care has principles that foster significance, generating meanings in the conditions of being-inthe-world and being-with-others. The theoretical conceptions that constitute care consider ontology, epistemology, and relationships, contemplating the practical and subjective knowledge of the care activity exercised ${ }^{(5)}$.

In teaching, concepts and definitions need to be worked on and developed to promote competencies and skills that direct the work process. The complexity in managing care consists in applying and articulating integrality so that there is an interrelationship of the conceptual functions that guide management and management activities with the cognitive, analytical, and behavioral competencies of care actions(6).

In the national scenario of academic education, nursing reflects an expressive reality with the creation of 684 new courses in the period from 2000 to 2012, representing 22\% of Health Graduates in 2012. A survey conducted in 2013 by the Oswaldo Cruz Foundation (Fiocruz) and the Federal Council of Nursing (Cofen) on the profile of Nursing in Brazil revealed that, according to the nature of the training institution, $35.6 \%$ graduated in public $\mathrm{HEl}, 57.4 \%$ in private educational institutions; and $8 \%$, among philanthropic and non-mentioned institutions. This information shows the progressive and constant expansion of Nursing in the national scenario and justifies the need to follow the transformations of training practices ${ }^{(7,8)}$.

Nursing education manifests itself in a still fragmented way; and, even in the face of the changes consented by the application of the National Curricular Guidelines of the undergraduate nursing course, the work organization method, as well as the actions and practices, demonstrate that managing overlaps with caring $^{(9)}$. Nursing also exercises management actions, which is a fundamental competence for assistance and has its purpose linked to the planning, coordination, and execution of activities and care strategies. Thus, this articulation demonstrates limitations in the practical-care-training context when the clinical exercise of care becomes secondary to administrative-technical actions ${ }^{(10)}$.

This gap proves the existence of a formative dichotomy, opposite to the recommendation of the discourse of integral care. To that end, the challenge arises from the difficulty of developing reflections based on the complexity of the relationships and the formative foundations that recognize the insertion of the nurse in the spaces of management/management of care as something essential for breaking the traditional teaching paradigm ${ }^{(11-12)}$.
Therefore, this study contests formative fragmentation, highlighting procedural teaching that needs a better engagement of the assumptions that conceptualize the production of knowledge and guide teaching and learning. In this context, for nursing, it is relevant to recognize what is idealized in a constant and unfinished way and what is operationalized based on the advances and demands of contemporary care ${ }^{(12)}$.

\section{OBJECTIVES}

To identify how nurses are trained to manage care.

\section{METHODS}

\section{Type of study}

It is an integrative review (IR) study, a method that allows synthesizing knowledge by incorporating scientific productions and evidence. This type of review provides the understanding and grouping of studies using a comprehensive analysis of the topic investigated ${ }^{(13-14)}$.

\section{Methodological procedures}

This study used the steps provided for the integrative review: 1) the identification of the theme and the elaboration of the question of guidance; (2) search of the literature using the criteria of inclusion and exclusion; (3) the extraction, summarization, and the organization of the information extracted from the selected studies, including the title and references, year/country, design methodology, outcomes, and the level of quality of the study; (4) critical analysis and a detailed description of the studies included in the review ensuring the eligibility by theme and appropriateness of the proposal, and as the object of study in the review; (5) the interpretation of the findings/outcomes; (6) a discussion of the results and the presentation of the review, which allowed us to categorize the three categories: Conceptions and feelings; Fragmentation of care and Training practices ${ }^{(13-14)}$.

\section{Collection of data}

The guiding question:"How does the training of nurses for care management occur"? conducted the process of searching and collecting the data. The acronym (PVO): population - students, teachers; variables - nursing education; outcomes (results) emphasis on training/care management defined it.

Considering the scope of the research, the area of knowledge (Health Sciences), and the subarea (nursing), the study selected four databases: Latin American \& Caribbean Health Sciences Literature (LILACS), Nursing Database (BDENF), Cumulative Index to Nursing and Allied Health Literature (CINAHL), Cochrane Library; and two electronic libraries, the Virtual Health Library (VHL) and the Scientific Electronic Library Online (SciELO).

The bibliographic survey, data collection, and analysis were carried out from May to October 2020. The study used the advanced search method with adjustment of the Medical Subject Heading (MeSH) subject descriptors and Health Sciences (DeCS) descriptors. We opted for the formulation of combined strategies 
for the selection of publications indexed in journals, with controlled descriptors associated with Boolean operators (Chart 1). The study carried out the search based on the conception of care management, which addresses different approaches to clinical nursing practice, including the management and management of care in the formative context, thus making searching a complex process when thought of in a more comprehensive perspective. Hence, the scope of the descriptors aimed to incorporate the available evidence on the theme "nursing care management" since there is no exact descriptor. The study sought to include descriptors related to the study theme, allowing the construction of a broader analysis of the literature. It considered the following inclusion criteria: original articles, full text available with access through the CAPES Journal Portal, no language delimitation, publications of the last five years (2016-2020). The study used a specific time frame to obtain more current studies, including as exclusion criteria: secondary studies, editorials, dissertations, theses, duplicate and/or repeated studies and not corresponding to the guiding issue of the study.

Chart 1 - Search process in selected databases and electronic libraries

\begin{tabular}{|c|c|c|}
\hline $\begin{array}{l}\text { Database / } \\
\text { electronic } \\
\text { libraries }\end{array}$ & $\begin{array}{l}\text { Search strategy } \\
\text { (DeCs / mesh Boolean operator) }\end{array}$ & Filters used \\
\hline LILACS & $\begin{array}{l}\text { "nursing care" or "bachelor degree in } \\
\text { nursing" or "nursing course" or "nursing } \\
\text { education" OR "nursing teaching" or } \\
\text { "nursing student" or "license in nursing" or } \\
\text { "research in nursing education" or "nursing } \\
\text { teacher practice" OR "undergraduate } \\
\text { nursing programs" or "research in clinical } \\
\text { nursing or "research in clinical practice } \\
\text { nursing" OR "practical nursing" }\end{array}$ & (2016-2020) \\
\hline BDENF & $\begin{array}{l}\text { "nursing care" OR "nursing education" } \\
\text { OR "nursing teaching" }\end{array}$ & $(2016-2020)$ \\
\hline CINAHL & $\begin{array}{l}\text { "nursing care" OR "school nurse" OR } \\
\text { "comprehensive health care" }\end{array}$ & $\begin{array}{c}\text { Full Text } \\
(2016-2020)\end{array}$ \\
\hline $\begin{array}{l}\text { Cochrane } \\
\text { Library }\end{array}$ & $\begin{array}{l}\text { "nursing care" or "school nurse" OR } \\
\text { "comprehensive health care" }\end{array}$ & $(2016-2020)$ \\
\hline BVS & $\begin{array}{l}\text { "nursing care" AND "nursing education" } \\
\text { AND "nursing teaching" }\end{array}$ & $\begin{array}{l}\text { Full texts and } \\
\text { last five years } \\
(2016-2020)\end{array}$ \\
\hline SCIELO & $\begin{array}{l}\text { "nursing care" AND "nursing education" } \\
\text { AND "nursing teaching" }\end{array}$ & $\begin{array}{c}\text { Article } \\
(2016-2020)\end{array}$ \\
\hline
\end{tabular}

\section{Data analysis}

The process of analyzing the studies began by selecting the titles, abstracts, and thematic analysis. This process was carried out by four nurse researchers, with three doctors with professional experience. The study used the adapted flowchart Preferred Reporting Items for Systematic Review and Meta-Analyses (PRISM) (15) to describe the search and selection process and detail the information pertinent to the search: identification, selection/ appreciation, and articles included, as shown below (Figure 1).

The CASP checklist - Critical Appraisal Skills Programme ${ }^{(16)}$ evaluated the analysis of methodological aspects and classification of the quality of evidence produced in the review studies, considering - A) - low risk of bias with good methodological quality (contemplating nine items); and (B) - moderate risk of bias with satisfactory methodological quality (including between 5 and 8 items) ${ }^{(17)}$.

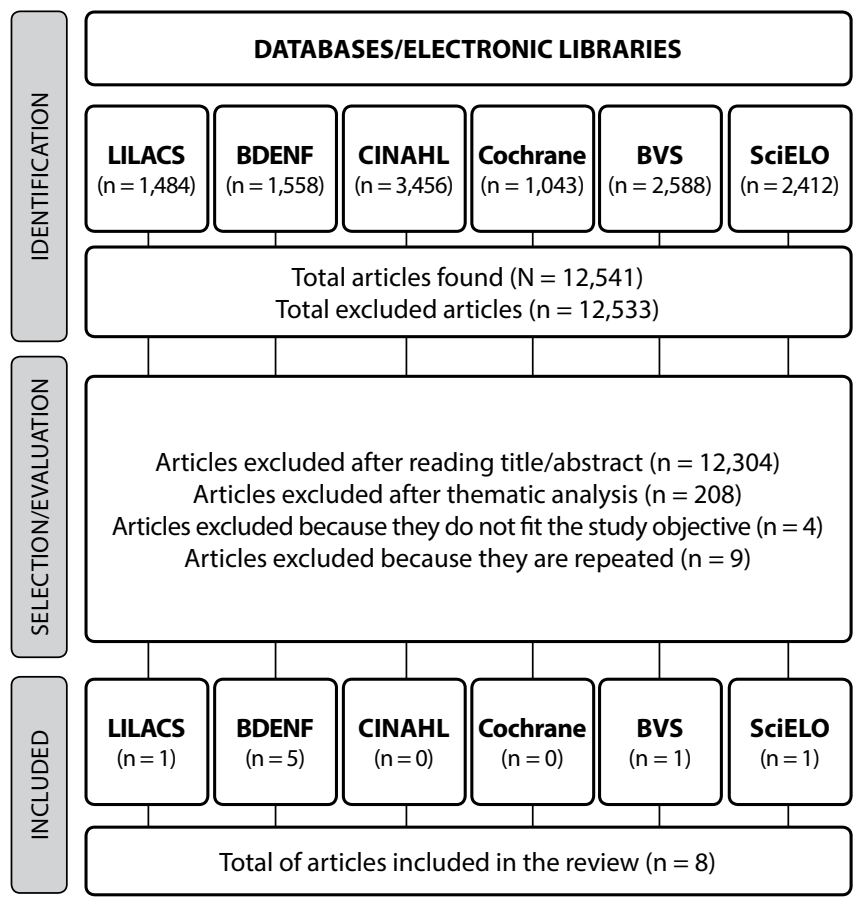

Figure 1 - Selection of studies on databases/electronic libraries

\section{Ethical aspects}

The study was exempted from consideration by the Research Ethics Committee because it was an integrative review.

\section{RESULTS}

The research identified 12,541 studies, excluding 12,533 subsequently. After analysis and careful reading of the titles and abstracts, 12,304 were excluded. The eligibility phase by theme and adequacy to the study proposal excluded 208 (four because they did not fit the study's objective; and nine because of repetition.) Finally, the sample was composed of eight articles that addressed relevant elements about the nurse training process for care management. Thus, the systematic search process contemplated the proposed objective of the study, responding to the research problem.

The main results found that the nurse training process for care management is fragmented, demonstrating a theoretical-practical disarticulation in its foundations, which shows a conceptual and applicative gap of managerial, bureaucratic, and non-integrative practice.

Regarding the methodological design, there was a predominance of studies of a qualitative nature, most of which, published in Brazil. One of the studies used the phenomenological approach of Martin Heidegger to analyze and understand the meanings of nursing care, and the other used the research itinerary of Paulo Freire to analyze the qualitative data collected. 
Chart 2 - Bibliometric information of the studies included in the review

\begin{tabular}{|c|c|c|c|c|}
\hline Title and references & $\begin{array}{c}\text { Year } \\
\text { Countries }\end{array}$ & $\begin{array}{l}\text { Design / number of } \\
\text { participants }\end{array}$ & Outcome & $\begin{array}{l}\text { Study quality } \\
\text { indicator } \\
\text { (CASP)* }\end{array}$ \\
\hline 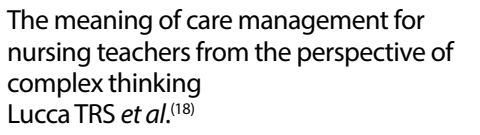 & $\begin{array}{l}2016 \\
\text { Brazil }\end{array}$ & $\begin{array}{l}\text { A qualitative and comprehensive } \\
\text { case study } \\
n=17 \text { teachers }\end{array}$ & $\begin{array}{l}\text { Concept of care management associated } \\
\text { with administration and management; a } \\
\text { fragmented concept }\end{array}$ & A \\
\hline $\begin{array}{l}\text { Integrality of care in nurse training: views } \\
\text { and experiences of the nursing academic } \\
\text { Santos ATS et al. } .^{(19)}\end{array}$ & $\begin{array}{l}2019 \\
\text { Brazil }\end{array}$ & $\begin{array}{l}\text { An exploratory, descriptive study } \\
\text { with a qualitative approach } \\
n=9 \text { academics }\end{array}$ & $\begin{array}{l}\text { The integrality of care is still fragmented, } \\
\text { which demonstrates fragility in the } \\
\text { formation process. }\end{array}$ & B \\
\hline $\begin{array}{l}\text { Pedagogical practice in nursing care } \\
\text { training } \\
\text { Tejada et al. }{ }^{(20)}\end{array}$ & $\begin{array}{l}2019 \\
\text { Peru }\end{array}$ & $\begin{array}{l}\text { A qualitative, exploratory, } \\
\text { descriptive study. } \\
n=21 \text { informants }\end{array}$ & $\begin{array}{l}\text { Pedagogical practice anchored in care } \\
\text { relationships, theoretical-practical } \\
\text { disarticulation of teaching, and teacher- } \\
\text { student bond }\end{array}$ & B \\
\hline $\begin{array}{l}\text { Senses of care for nursing scholars: } \\
\text { Heideggerian contributions to teaching } \\
\text { Garcia FR et al. }{ }^{(21)}\end{array}$ & $\begin{array}{l}2020 \\
\text { Brazil }\end{array}$ & $\begin{array}{l}\text { A qualitative study, from the } \\
\text { phenomenological perspective of } \\
\text { Martin Heidegger } \\
n=13 \text { academics }\end{array}$ & $\begin{array}{l}\text { It reveals an understanding that involves } \\
\text { the sense of care, presenting perceptions } \\
\text { about the dichotomy of teaching and } \\
\text { practice. }\end{array}$ & B \\
\hline $\begin{array}{l}\text { Care management from the perspective } \\
\text { of supervising nurses } \\
\text { Costa MAR et al. }{ }^{(22)}\end{array}$ & $\begin{array}{l}2017 \\
\text { Brazil }\end{array}$ & $\begin{array}{l}\text { Qualitative study } \\
\mathrm{n}=15 \text { nurses }\end{array}$ & $\begin{array}{l}\text { The management of care presents } \\
\text { itself in a fragmented way, still linked to } \\
\text { bureaucratic organizational actions and } \\
\text { material, physical and human resources. }\end{array}$ & B \\
\hline $\begin{array}{l}\text { Training for integral Care: perception of } \\
\text { nursing teachers and students } \\
\text { Rangel RF et al. } .^{(23)}\end{array}$ & $\begin{array}{l}2017 \\
\text { Brazil }\end{array}$ & $\begin{array}{l}\text { An exploratory-descriptive study } \\
\text { with a qualitative approach. } \\
\mathrm{n}=7 \text { teachers and } 6 \text { students }\end{array}$ & $\begin{array}{l}\text { The integrality of care needs to be (re) } \\
\text { thought throughout the academic training } \\
\text { to transpose the traditional/ biomedical } \\
\text { teaching. }\end{array}$ & A \\
\hline $\begin{array}{l}\text { Nurses' perception towards the teaching- } \\
\text { learning process of Nursing management } \\
\text { Silva AM et al..(24) }\end{array}$ & $\begin{array}{l}2018 \\
\text { Brazil }\end{array}$ & $\begin{array}{l}\text { A qualitative study guided by } \\
\text { Paulo Freire's research } \\
\mathrm{n}=3 \text { outputs }\end{array}$ & $\begin{array}{l}\text { The teaching of care needs to be worked in } \\
\text { a transversal way to professional practice. }\end{array}$ & B \\
\hline $\begin{array}{l}\text { Assessment of Nursing Care and Teaching: } \\
\text { a Qualitative Approach } \\
\text { Linares JMM et al. } \text {. }^{25)}\end{array}$ & $\begin{array}{l}2019 \\
\text { Spain }\end{array}$ & $\begin{array}{l}\text { Qualitative, exploratory- } \\
\text { descriptive study } \\
n=12 \text { nursing professionals and } \\
12 \text { students }\end{array}$ & $\begin{array}{l}\text { The evaluation of nursing care and the } \\
\text { theoretical-practical gap between the } \\
\text { implementation of evidence-based and } \\
\text { experience-based practices }\end{array}$ & A \\
\hline
\end{tabular}

${ }^{*}$ CASP - Critical Appraisal Skills Programme.

Concerning the description and characterization of the participants, the studies included teachers and students from undergraduate courses in nursing, egresses, and professionals working in care. The following synoptic chart (Chart 2) details other particularities, which presents an analytical synthesis of the bibliometric information of the studies included in the review.

\section{DISCUSSION}

Based on the analysis, the study constituted three thematic categories: conceptions and feelings, fragmentation of care, and training practices.

\section{Conceptions and senses}

The conceptions inherent to care management, indicated as incipient in some formative contexts, presented a discussion on the need to work its meaning in an integral and articulated way. It is necessary to understand the concepts to establish uniformity in their application and give significance to what is understood by managing health care ${ }^{(18)}$. From the perspective to build a caring approach, limited conceptions are still predominant, intended to cure and disease, distancing from the management of integral care proposal(19).
In addition to these premises, the construction of the meaning "care" can also occur by the representation of the teaching figure since the interpersonal relationships established by the teachings, posture and professional performance interfere in the formative process of teacher-teaching-care bonds ${ }^{(20)}$.

Based on the understanding of care as a phenomenon, the study revealed a connection to the technical act that transforms care into a usual activity linked to the occupation, generating an issue to correspond to the particularities and human needs of each individual ${ }^{(21)}$.

Supporting nursing care management involves a dialectical relationship of expertise characterized by an interface of correlations of technical, organizational, and social nature. Thus, the practice, result of these relationships is accomplished by the communication that is structured in the nurses' fields of activity ${ }^{(26)}$.

Considering care as an integral therapy, that is, not only related to physical healing, the understandings around the emotional, personal, ethical, and scientific aspects are still little discussed in the training context. However, to strengthen a practice that has care as a central focus, it is necessary to build environments that cultivate relationships based on care, which value the senses, perspectives, and subjective aspects so that there is the contemplation of affective notions, values, and the relational sphere ${ }^{(27-28)}$. 
Notions about care management are a complex function that is built collectively. It is the result of an interdependent conceptualization that still refers to the elaboration of a concept inherent to the managerial, administrative, and bureaucratic activity, which emphasizes acts such as resource management and people management. Thus, direct actions denote attitudes to meet the needs and demands of the patient, encompassing respect, individuality; and administration and management services pursue indirect actions. This conception allows identifying weaknesses in the construction of knowledge since it still happens in a divided way, mainly because it does not include other components that act following the practical exercise of its application and/or as a concrete action ${ }^{(22)}$.

As an object of study essentially produced by nursing, thinking about what constitutes care is to understand that all actions integrate multiple dimensions. It consists of six interconnected dimensions: individual, family, professional, organizational, systemic, and corporate. They aim to improve the practice and the reflections necessary for its development. Care and management are complementary concepts that influence each other and together form a complex sense unit. As a result of the harmonization of these dimensions, these concepts have the meaning corresponding to the macro-concept "integral care management" and are, respectively, presented as product and producers of the final process equivalent to the actions of nursing ${ }^{(2)}$.

\section{Fragmentation of care}

There is a disarticulation between what is learned and what is established in practices, evidencing a context of health training guided by actions with an emphasis on management, administration, planning, and organization ${ }^{(18)}$.

The teaching-theory-care-practice relationship is based on a complexity that transposes the knowledge acquired in the classroom, and it is essential to incorporate real senses, consistent with the daily actions of health work operated by nursing professionals ${ }^{(20)}$.

The care still offered and used instrumentally, linked to the procedure, shows the urgency of seeking new alternatives to implement curricular changes, anchored in humanistic and welcoming perspectives that value the individual in a holistic way and that overcome the precepts employed by hospital-centric training ${ }^{(21)}$.

The literature presents integrality as not very clear and still reveals it as an isolated component of management. However, it is still contextualized in its senses and relationships when identified as the pillar of nursing. Few studies illustrate such relationships, and its evidence demonstrate gaps in the consolidation of comprehensive care ${ }^{(26)}$.

Amid the distortions between conceptions and practices that concern care, teaching becomes a challenge, highlighting the difficulty in transposing theorization. It denotes a didactic motivated by the traditional perception of care still linked to healing, revealing a questionable apprehension of knowledge that, in a non-systematic way, devalues the deeper epistemological thinking in the relationships and expanded concepts of health ${ }^{(27)}$.

As challenges, there are also the changes in teaching over the years, which relate to the new requirements in the profile of nurses, highlighting the restructuring of knowledge and to care-caution actions as well as the disruption of traditional paradigms. To that end, the study suggested more efficient care, based on problematization and approach to practicing beyond the technical-scientific teaching ${ }^{(27)}$.

The fragmentation of care permeates through reflection on educational advances considering the performance, practice, conceptions of health and care within the political-social and cultural contexts in which nurses are inserted. Based on a comparative critical reflection on Nursing Education conducted in China, Brazil, and Canada, countries with similarities in the policies for access to health services, the study concluded that nursing education needs to advance in terms of pedagogical processes and curricula, aligning a training directed to each context, with knowledge about health systems and particular demands ${ }^{(29)}$.

On the other hand, greater integration between care and its management in the practice of nurses requires training that considers elements of the student's own experience and a pedagogical action that promotes professional development with the use of different educational methods and reflexive promotion of learning ${ }^{(30)}$.

In addition to these factors, we highlight the transformative role that nurses have in the face of a scenario of changes in health systems, health profile, and consequent demands for care. Thus, their training needs to be aligned with attention focused on patient and family, strategies to promote well-being with a focus on health promotion and continued care ${ }^{(31)}$.

\section{Training practices}

How the actions linked to care management are articulated was represented by the need to align pedagogical processes with the application of the principle of integrality in practical activities. In this regard, it was fundamental to discuss learning methods in the clinical care field and management beyond the operative act of nursing systematization ${ }^{(28)}$. The teachers' perceptions demonstrated a dichotomy between the discourse and the difficulties of conciliation in an associated management centered on care, but not addressed in an integrated way in the curricular components and/or pedagogical actions ${ }^{(18)}$.

The relationship of models, methodologies, and management of pedagogical strategies based on problem-based learning $(A B P)$, integrated curriculum, and didactic transformations is also mentioned for dealing with potentiating components to be employed in training practices centered on the integrality ${ }^{(20)}$.

Thus, the formative process needs to stimulate reflections, encourage new thoughts based on teacher-student cooperation, exploring domains and skills through methodological resources that induce meaningful learning about care. However, the production of care is part of a process that requires changes in the traditional teaching model. To that end, based on student perceptions, students recognize and assign responsibility to teachers regarding the application of educational strategies in line with aspects of development and learning that go beyond the established knowledge. Above all, the teaching conceptions identify that, in addition to these strategies, it is necessary to link health services to the training process, seeking to establish 
a teaching-service construction in an integrated and shared way to contemplate the effective production of care on real perspectives in the most diverse scenarios of professional performance ${ }^{(23)}$.

Given these aspects, some difficulties, permeated by the early construction of the senses in educational models, are characterized by the non-intersectoral approach and the fragmentation of knowledge, and the absence of skills that deepens the understanding of work processes and roles pertinent to the dimensions of care. The demands generated by these aspects are represented by the prevalence of linear thinking, bringing to light concerns regarding the provision of care and professional performance that require broad competence in administration and management, but which are still configured as poorly explored elements in health education ${ }^{(24)}$.

However, for the production of efficient changes in praxis related to care, it is necessary to stimulate a personal formation based on the principles of self-care, so that the caregiver realizes himself as such, allowing the transcendence of the technique and the reflection on the quality and excellence of the issues that involve the subjectivities in the care actions offer ${ }^{(21)}$.

The establishment of care stems from the constant structuring of the relationships between subjects, health teams, and generated activities. It comes from the scope of integral care when the dimensions of interdisciplinarity are expanded, the traditional models of work organized by the professions are replaced, and units of multi-professional health teams are established. This multifaceted dialogue suggests modifications capable of contemplating the scope of solving problems arising from health needs and the segmentation of care ${ }^{(26)}$.

Among the mechanisms for the full accomplishment of integral care, communication and planning are essentially relevant factors to achieve both the principle of integrality and, in its implications, the Systematization of Nursing Care (SAE), which is addressed as a predictor factor in the ordering of care since it is a tool that promotes quality and organizes care in a systematic way ${ }^{(26)}$.

Curricula lack pedagogical synchronization with nursing actions to provide opportunities for health care. The contents need to consider, in a coherent way, the proposals of an integrative training with the new trends, offering subsidies for a provider of care ${ }^{(28)}$.

In clinical settings, it is still challenging to apply interventional guidelines that value the quality of the actions provided; and, although it is favorable to aggregate and improve new training, actions cannot be performed in a generalized way: it is necessary to promote nursing care consistent with the specificities of the environments and spaces that promote care ${ }^{(25)}$.

In addition, research is needed in this field, especially when discussing the acquisition of nursing skills for professional practice $^{(31)}$. Studies have revealed a demand in the development of critical thinking and clinical and technical skills ${ }^{(31-32)}$ as well as more comprehensive preparation of newly graduated nurses to work in clinical environments and management, especially in decision making, planning, prioritization, and coordination ${ }^{(33)}$.

\section{Study limitations}

The limitations are related to the scant scientific production related to the presented topic, the weaknesses of the training, the lack of resolutive proposals to promote new training approaches, and the non-definition of concepts and terminologies little used in the curricular components. The propositions mentioned herein are limited by the need for research for improvement in the field of teaching and practical application in an integrated way, and it is necessary to foster more in-depth debates on the practical and teaching challenges contextualized here.

\section{Contributions to the field of nursing}

Nursing practice is achieved by the dynamism of the act of care, and this research presents its contribution to rethinking the practices implemented in the curricular components today. On the one hand, the study identified existing needs and demands that need to be met by quality care management; and, on the other hand, it was possible to understand the progress in the fundamental axes leading to didactic pluralism, humanization, relationships of care, and importance given to the themes with an emphasis on the training of nurses for care management.

In addition, talking about contributions proposes new ways that, through challenges, can ask about what the practice and training would be, the environment that would help in adhering to such proposals, and how studies and scientific evidence, in a transdisciplinary way, could shape and create which would be ideal for comprehensive care.

\section{FINAL CONSIDERATIONS}

The training of nurses for the management of care in pedagogical practices is fragmented, revealing a necessary reflection on the curricular bases that direct nursing training. These methodological and formative challenges need to be aligned with an integrative proposal so that the fragmented dimensions in relationships are addressed and worked on in the pedagogical projects of the undergraduate courses and the practice environments. To bring about changes in the professional profile and health models demands a new look at the conceptions and meanings that guide nursing care in the scope of both care and health care practices.

In the practical field, research needs to address conceptions inherent to teaching processes with a focus on concepts, significance, and application, engaging the development of macro skills to transpose care beyond theory. Thus, the ambiance of health scenarios is essential to generate idealized learning by the re-signification of care. Therefore, knowing how to care within a teaching context that sometimes does not incorporate care as an intimate element of the human and professional personality exerts a mistaken perception about the care provided, intending to add value to the practice, and about the act of understanding the premises under which the exercise of nursing care needs to be carried out.

\section{FUNDING}

Scholarship for academic education in the master's degree modality of the Cearense Support Foundation for Scientific and Technological Development - FUNCAP. 


\section{REFERENCES}

1. Queirós PJP. Reflections for a nursing epistemology. Texto Contexto Enferm. 2014;23(3):776-81. https://doi. org/10.1590/0104-07072014002930013

2. Siewert JS, Rodrigues DB, Malfussi LBH, Andrade SR, Erdmann AL. Management of integral care in nursing: reflections under the perspective of complex thinking. REME. 2017;21:e-1047. https://doi.org/10.5935/1415-2762.20170057

3. Cecilio LCO. Apontamentos teórico-conceituais sobre processos avaliativos considerando as múltiplas dimensões da gestão do cuidado em saúde. Interface (Botucatu). 2011;15(37):589-99. https://doi.org/10.1590/S1414-32832011000200021

4. Mororó DDS, Enders BC, Lira ALBC, Silva CMB, Menezes RMP. Concept analysis of nursing care management in the hospital context. Acta Paul Enferm. 2017;30(3):323-32. https://doi.org/10.1590/1982-0194201700043

5. Gomes ET, Brandão BMGM, Abrão FMS, Bezerra SMMS. Contributions by Leonardo Boff for the understanding of care. J Nurs UFPE. 2018;12(2):531-6. https://doi.org/10.5205/1981-8963-v12i2a23563p531-536-2018

6. Tenório HAA, Souza IB, Gomes Junior EL, Santos RFEP, Correia DS, Viana LS, et al. Nursing management and administration: perspectives of student performance. J Nurs UFPE. 2019;13:e240535. https://doi.org/10.5205/1981-8963.2019.240535

7. Frota MA, Wermelinger MCMW, Vieira LJES, Ximenes Neto FRG, Queiroz RSM, Amorim RF. Mapping nursing training in Brazil: challenges for actions in complex and globalized scenarios. Cienc Saude Colet. 2020;25(1):25-35. https://doi.org/10.1590/1413-81232020251.27672019

8. Conselho Federal de Enfermagem (BR). Pesquisa perfil da enfermagem no Brasil: banco de dados [Internet]. Brasília, DF: Cofen; 2013[cited 2021 May 11]. Available from: http://www.cofen.gov.br/perfilenfermagem/index.html\#apresentacao

9. Gelbcke FL, Reibnitz KS, Prado ML, Lima MM, Kloh D. A práxis da enfermeira e a integralidade no cuidado. Enferm Foco. 2011;2(2):116-9. https://doi.org/10.21675/2357-707X.2011.v2.n2.108

10. Ferreira VHS, Teixeira VM, Giacomini MA, Alves LR, Gleriano JS, Chaves LDP. Contributions and challenges of hospital nursing management: scientific evidence. Rev Gaucha Enferm. 2019;40:e20180291. https://doi.org/10.1590/1983-1447.2019.20180291

11. Figueiredo GO, Orrillo YAD. Currículo, política e ideologia: estudos críticos na educação superior em saúde. Trab Educ Saude. 2020;18(suppl 1):e0024880. https://doi.org/10.1590/1981-7746-sol00248

12. Valenzuela-Suazo SV. Aplicación de la teoría en la investigación del cuidado [Editorial]. Rev Enferm Inst Mex Seguro Soc [Internet]. 2019[cited 2020 Aug 4];27(3):124-7. Available from: http://revistaenfermeria.imss.gob.mx/editorial/index.php/revista_enfermeria/article/ view/1101/1038

13. Mendes KDS, Silveira RCCP, Galvão CM. Revisão integrativa: método de pesquisa para incorporação de evidências na saúde e na enfermagem. Texto Contexto Enferm. 2008;17(4):758-64. https://doi.org/10.1590/S0104-07072008000400018

14. Mendes KDS, Silveira RCCP, Galvão CM. Use of the bibliographic reference manager in the selection of primary studies in integrative reviews. Texto Contexto Enferm. 2019;28:e20170204. https://doi.org/10.1590/1980-265x-tce-2017-0204

15. Galvão TF, Pansani TSA, Harrad D. Principais itens para relatar revisões sistemáticas e meta-análises: a recomendação PRISMA. Epidemiol Serv Saude. 2015;24(2):335-42. https://doi.org/10.5123/S1679-49742015000200017

16. Critical Appraisal Skills Programme. CASP [qualitative studies] checklist [Internet]. Oxford: CASP; 2018 [cited 2020 Aug 12]. Available from: https://casp-uk.net/casp-tools-checklists/

17. Belém JM, Pereira EV, Rebouças VCF, Borges JWP, Pinheiro AKB, Quirino GS. Theoretical, methodological and analytical aspects of ethnographic research in obstetric nursing: an integrative review. Rev Esc Enferm USP. 2020;54:e03547. https://doi.org/10.1590/ S1980-220X2018034203547

18. Lucca TRS, Vannuchi MTO, Garanhani ML, Carvalho BG, Pissinati PSC. The meaning of care management attributed by nursing faculty members from the viewpoint of complex thinking. Rev Gaucha Enferm. 2016;37(3):e61097. https://doi. org/10.1590/1983-1447.2016.03.61097

19. Santos ATS, Oliveira CB, Passos MC, Andrade ASA, Gallotti FCM. Integralidade do cuidado na formação do enfermeiro: visões e vivências do acadêmico de enfermagem. Enferm Foco. 2019;10(1):122-6. https://doi.org/10.21675/2357-707X.2019.v10.n1.1397

20. Tejada S, Ramirez EJ, Díaz RJ, Huyhua SC. Práctica pedagógica en la formación para el cuidado de enfermería. Enferm Univ. 2019;16(1):41-51. https://doi.org/10.22201/eneo.23958421e.2019.1.577

21. Garcia FR, Rendón DCS, Nazareth JB, Amorim TV, Sena CA, Salimena AMO. Directions for nursing academics towards care: heideggerian contributions to education. J Nurs UFPE. 2020;12:313-8. https://doi.org/10.9789/2175-5361.rpcfo.v12.6977

22. Costa MAR, Souza VS, Oliveira JLC, Teston EF, Matsuda LM. Care management from the perspective of supervising nurses. Rev Rene. 2017;18(4):476-82. https://doi.org/10.15253/2175-6783.2017000400008

23. Rangel RF, Backes DS, Ilha S, Zamberlan C, Siqueira HCH, Costenaro RGS. Training for integral care: perception of Nursing teachers and students. J Res Fundam Care Online. 2017;9(2):488-94. https://doi.org/10.9789/2175-5361.2017.v9i2.488-494

24. Silva AM, Celich KLS, Silva TG, Souza SS, Bitencourt JVOV, Bertoncello KCG. Nurses' perception towards the teaching-learning process of Nursing management. J Res Fundam Care Online. 2018;10(4):1098-102. https://doi.org/10.9789/2175-5361.2018.v10i4.1098-1102 
25. Martínez-Linares JM, Martínez-Yébenes R, Andúrjar-Afán FA, López-Entrambasaguas OM. Assessment of nursing care and teaching: a qualitative approach. Int J Environ Res Public Health. 2019;16(15):2774. https://doi.org/10.3390/ijerph16152774

26. Sousa SM, Bernardino E. Nursing management for integral care: integrative review. J Nurs UFPE. 2015;9(6):8312-21. https://doi. org/10.5205/1981-8963-v9i6a10592p8312-8321-2015

27. Coelho MP, Menezes HF, Rosas AMMTF, Rosa AF, Pinto ACS, Saraiva RJ. Teaching in nursing care of undergraduate courses in Brazil: integrative review. J Nurs UFPE. 2016;10(2):647-56. https://doi.org/10.5205/1981-8963-v10i2a11001 p647-656-2016

28. Zambrano Santos RO, Macías Alvia AM, Solórzano Solórzano SE. Fundamento pedagógico del cuidado humano en la práctica de enfermería. Rev Digit Postgrado [Internet]. 2019[cited 2020 Jul 20];8(3):1-7. Available from: http://190.169.30.98/ojs/index.php/rev_dp/ article/view/17081

29. Vila V, Zhuang J, Tan E, Thorne S. Reflections on nursing educational advancement within diverse and evolving national cultural contexts. Int J Nurs Educ Scholarsh. 2018;15(1):20180017. https://doi.org/10.1515/ijnes-2018-0017

30. Haugland $B \varnothing$, Lassen RM, Giske T. Professional formation through personal involvement and value integration. Nurse Educ Pract. 2018;29:64-9. https://doi.org/10.1016/j.nepr.2017.11.013

31. Missen K, Mckennal L, Beauchamp A. Registered nurses' perceptionsof new nursing graduates'clinical competence: a systematic integrative review. Nurs Health Sci. 2016;18(2):143-53. https://doi.org/10.1111/nhs.12249

32. Salmond SW, Echevarria M. Healthcare transformation and changing roles for nursing. Orthop Nurs. 2017;36(1):12-25. https://doi. org/10.1097/NOR.0000000000000308

33. Sadeghi A, Oshvandi K, Moradi Y. Explaining the inhibitory characteristics of clinical instructors in the process of developing clinical competence of nursing students: a qualitative study. J Family Med Prim Care. 2019;8(5):1664-70. https://doi.org/10.4103/jfmpc.jfmpc_34_19 